\title{
Women and the Politics of (Dis) Embodiment: Linking Corporeality, Sexuality and Subjectivity in Rani Manicka's The Rice Mother
}

\author{
Manmeet Kaur Senthok Singh
}

\begin{abstract}
This study comprises a feminist reading of Rani Manicka's The Rice Mother through Elizabeth Grosz's (1994) theory of corporeal feminism. Review of related literature reveals that female corporeality and sexuality are key sites of women's oppression under patriarchy. Despite this, literature review discloses that the state of feminist-informed literary studies on female body politics in Malaysia is dismal because of the taboos surrounding the subject matter. This study aims to fill the literary void brought about by the lack of feminist studies on the female body in Malaysian literature in English. Highlights of the present study include exposing various forms of patriarchal control over female corporeality and sexuality, exploring the effects of such hegemony on female subjectivity and examining the women characters' strategies of resistance to regain control over their bodies and sexuality. Findings reveal that while the female body is subject to sexual violence and domestic, sexual and reproductive servitude; female sexuality is oriented towards procreation and the gratification of men's needs. However, what makes Manicka's novel a worthwhile literary endeavour is not the victim status of her women characters, but the ambivalence that results from the clash of voices in their subjectivities which urges them to resist patriarchy and reclaim the most intimate aspect of their being.
\end{abstract}

Index Terms - Female body, female sexuality, feminism, Rani Manicka, resistant subjectivities.

\section{INTRODUCTION}

For several thousand years, the female body has been used as a canvas for painting the lineaments of patriarchal domination and exploitation. Enormous efforts - under the pretext of biological determinism, social norms, cultural traditions and religious practices — have been made by patriarchy to maintain control over the female body and claim access to female sexuality. While female corporeality has been defined in terms of passivity, dependence, weakness, irrationality and volatility; female sexuality has been oriented towards procreation and the fulfilment of men's needs. In each state, the female figure is reduced to a mere object to be manipulated by men for their own gratifications, robbing women of subjectivity, resulting in disembodiment - the process by which the female body becomes split from self, as though it does not belong to it and has no agency.

In spite of this, the state of feminist-informed literary studies on female body politics in Malaysia is dismal because

Manuscript received April 4, 2015; revised June 21, 2015.

Manmeet Kaur Senthok Singh is with the Department of Languages and Linguistics, Faculty of Arts and Social Science, Universiti Tunku Abdul Rahman, Perak, Malaysia (e-mail: manmeetk@utar.edu.my). of the taboos surrounding the subject matter. The taboos surrounding women's body and sexuality can be attributed to the prevailing socio-cultural norms and religious traditions that have made it "embarrassing" or "undesirable" to talk about such issues in a constructive manner in public [1]. Comments such as "It is not part of our culture" or "Our religion does not permit such things" are often used as excuses to avoid pressing discussions related to female corporeality and sexuality [1].

Researcher, Jerome [2], opines that although "the changing sexual behaviours of women in contemporary times have been documented in literary works by Malaysian writers in English," feminist discussions on these issues are inadequate. Literature review discloses that except for Lily Rose Tope's (2010) The Hushed Identity: Malay Ethnicity and Sexuality in Malaysian and Singaporean Literature in English, Wan Roseleezam Wan Yahya's (2002) The Female Body in K.S. Maniam's The Sandpit: Womensis and Nor Faridah Abdul Manaf's (2001) Sexuality in Post-Independence Anglophone Writing by Three Malaysian Muslim Women Writers, there is hardly any significant critical work exploring the relationship between female corporeality, sexuality and subjectivity. This has resulted in a literary gap, an emptiness which justifies the need for this study. At this point it is also important to note that to date there has been no published scholarly works on Rani Manicka's novel which picked up the prestigious Commonwealth Writers' Prize in 2003.

As such, this study attempts a corporeal feminist reading of Rani Manicka's The Rice Mother. It strives to break the silences and taboos enshrouding the female body and sexuality in Malaysia, by opening up honest discussions about women's experiences of their bodies and desires via literary texts. This is because Manicka presents the female body in manners which contest what is condoned by patriarchy. She invites readers "to see, touch and smell a body made of organs, whether they are exhibited with satisfaction or horror" [3]. She writes "about their bodies, about their sexuality...about the adventure of such and such a drive, about trips, crossings, trudges, abrupt and gradual awakenings, discoveries of a zone at one time timorous and soon to be forthright" [4]. Cixous [4] stresses that women's "writings" such as Manicka's and "the job of analysis and illumination" which this study undertakes are acts that "....will not only 'realise' the decensored relation of woman to her body, to her womanly being, giving her access to her native strength; it will give her back her immensely bodily territories which have been kept under seal; it will tear her away from the superegoised structure..." 


\section{RESEARCH OBJECTIVES}

The objectives of this study are as follows:

1) To expose various forms of patriarchal control over the female body and sexuality in Rani Manicka's The Rice Mother

2) To explore the effects of patriarchal control over the female body and sexuality on female subjectivity in Rani Manicka's The Rice Mother

3) To examine the female characters' strategies of resistance against patriarchal subjugation of the body and sexuality in Rani Manicka's The Rice Mother

\section{CONCEPTUAL FRAMEWORK}

The selection of methodology for the present study is informed by Grosz's [5]-[7] corporeal feminist theory and two conceptual tools. They include Kandiyoti's [8] and Katrak's [9] notions on patriarchal bargains and Davies' [10] and Weedon's [11] notions on reinstating a liberated female subjectivity undistorted by patriarchy.

\section{A. Corporeal Feminism}

A corporeal feminist framework aspires to "refigure the body" so that "it moves from the periphery to the centre of analysis, so that it can be understood as the very 'stuff' of subjectivity" [6]. For corporeal feminists, the body is deemed crucial to understanding women's physical, social and psychical existence. Thus, it can be said that what women feel inside their bodies and how they experience their bodies are crucial starting points from which they establish subjecthood and self-knowledge.

Corporeal feminism accounts for "the biological, or universal, trans-historical elements of the biological body" [12]. For example, female biological specificity like menstruation and menopause and female bodily experiences like sexual pleasure and illness are accounted for without reducing women to biology. Corporeal feminists recognise the need to celebrate and honour female biological specificity and distinct female bodily experiences which have long been subjects of taboo, superstition, fear and suspicion. Grosz [6] asserts that ignoring the unique specificities and experiences of the female body results in a literary tradition based on partial blindness, pushing the already downtrodden woman into deeper shadow.

Corporeal feminism also views the body as an inscriptive surface. Grosz [7] explains: "As pliable flesh, the body is the unspecified raw material of social inscription that produces subjects as subjects of a particular kind". In other words, corporeal feminism is concerned with the processes by which the subject is "marked, scarred, transformed, and written upon or constructed by the various regimes of institutional, discursive, and nondiscursive power as a particular kind of body" [7]. The framework looks at the body's capacity to be "moulded, constructed, socially informed or culturally specified" [5]. For the purpose of this study, the body is seen as a surface that is inscribed on by various patriarchal socio-cultural norms and religious dictates.

Corporeal feminism also encompasses the notion of agency. The female body is not merely a passive entity "marked, scarred, transformed, and written upon or constructed" by patriarchal ideologies [7]. It is capable of acting as an "object of resistance to power" because "women's specificities, corporeality and subjectivities" are not "logically or biologically fixed" [5]. They can be "contested", "redefined", "reconceived" and "reinscribed" [5].

\section{B. Patriarchal Bargains}

Kandiyoti [8] argues that women are not merely weak, submissive, docile and passive victims of patriarchy. On the contrary, they are highly capable of becoming active agents of resistance, seeking recognition as subjects in their own right, by engaging in patriarchal bargains.

Katrak [9] adds that in resisting patriarchal domination, "women make strategic use of their bodies, often their only available avenue for resistance". For instance, they resist patriarchal domination via "the use of speech, silence, starvation, illness and so on" [8]. According to Bakhtin [9], "such bodily expression is an important means of liberating human consciousness from a verbal, hierarchical perception of the work [to] opening up the possibility for a horizontal understanding of change". Katrak [9] asserts that "female resistances are undertaken with self-consciousness and remarkable creativity that decides to take risks and confront domination selectively and strategically in the interest of self-preservation".

As such, in this study, I shall examine not only various patriarchal social, cultural and religious structures that exert power and control over the female body and sexuality in the selected novel, but also the female characters' strategies of resistance against patriarchal subjugation of the body and sexuality.

\section{Resistant Subjectivities}

This study is specifically concerned with examining female subjectivity and its role in bringing about female agency and overall social change. Female subjectivity here refers to "the conscious and unconscious thoughts and emotions of the individual, her sense of herself and her ways of understanding her relation to the world" [11]. Subjectivity is not something that people are born with. Instead, it is constituted by specific dominant practices and discourses that individuals live in. In other words, an individual's subjectivity develops from her past experiences, social interaction and the socio-political, cultural, historical milieu she lives in.

Davies [10] writes: "Examining any individual's subjectivity is a way of gaining access to the constitutive effects of the discursive practices through which we are all constituted as subjects and through which the world we all live in is made real". However, this does not mean that individual subjects are devoid of any participatory role in the construction of self. They are not reduced to docile bodies, with control totally residing in the powerful devices of surrounding discourses. This is because at the heart of subjectivity lies "a fluid interaction in constant motion and open to alteration by self-analysing practice" [13]. Hall [14] stresses: "We are subject to discourse, not simply subjects through discourse with ability to turn around, contemplate, and rework our subjectivity at will".

For the purpose of this study, I will examine the repressed female subjectivity of the women characters in Manicka's novels. I will study the tensions and instabilities inherent in 
the subjectivities of these women characters through a thorough examination of various patriarchal discourses which both constitute and suppress them. In addition, I will look at the women characters' capacity for awareness and reflection of their current subjectivities and their ability to make choices based on these reflections which result in action - the women characters' ability to take active and creative control over their bodies and sexuality through an awakened subjectivity.

\section{FINDINGS}

\section{A. Menarche: Cause for Celebration or Denigration?}

Menarche, or the first occurrence of menstruation, is a natural physiological process which marks the onset of a woman's sexual and reproductive capacities. It is an event which symbolises growth and maturity, identity formation and development and the beginning of womanhood - a rite de passage. In other words, it is a positive and powerful experience that calls for celebration.

However, this does not hold true for Lakshmi. Her experience of menstruation is distorted by a patriarchal lens. As soon as she reaches puberty, she is secluded for seven days in a small room with the windows nailed shut and doors locked. Her mother gives her food in half a coconut shell which is to be dispensed after use instead of handing her food in a plate like she usually does. Her diet is restricted to raw eggs, aubergines and sesame seed oil. "Why?" you may ask.

Among orthodox Hindu groups, menstruation is viewed as a curse, a source of pollution and defilement. A menstruating woman is considered impure and any contact with her or the objects that she touches can cause harm, illness and death to her family members. Hence, the need for seclusion and disposable food containers. As for the dietary restrictions, they have got to do with "the belief that menstruation is a curse, a diseased condition which is harmful to health and consequently should be reduced as much as possible" [15]. As such, food stuff like flesh, meat and sweetmeats are forbidden for they are believed to heat the blood, arouse sexual desire and increase the severity of the flow.

Rather than being viewed as a normal physiological process that affects half of the world's population, menstruation then becomes a socio-cultural product closely associated with the low status of women. It comes laden with negative connotations such as taboo, curse, impurity, pollution, defilement and punishment.

Truth is the imposition of various restrictions and confinements on women at the onset of menarche under the pretext of religion has got to do with the regulation of female sexuality. The author reveals that Lakshmi is confined to a tiny room with the windows nailed shut because "It was the custom, for no self-respecting family was prepared to risk the possibility of adventurous boys climbing up coconut trees to peek at the newly found, secret charms of their daughters" [16]. In order to safeguard Lakhsmi's "newly found, secret charms" (read: budding female sexuality), Lakshmi is removed from the public sphere and restricted to the private sphere: "I was then simply confined indoors and made to learn to do women's things" [16].
All of these myths and misconceptions surrounding menarche and menstruation and the resulting confinement and restrictions imposed on Lakshmi result in adverse effects on her life. Because the beginning of her menstrual period is saddled with stigma and taboo, connected to a sense of confusion, disunion and loss of joy, and associated with feelings of being cursed and unclean, she feels highly disembodied. She feels as though her body has become disconnected from her sense of self, as though it no longer belongs to her, as though it is devoid of agency. She suffers from a severe conflict between her sense of self and an imposed model of femininity which is bent on preparing her for wifehood and motherhood.

It is important to note that Lakshmi does not consider the process of menstruation itself as an obstacle that impedes her life or hinders her abilities in any way. There is no mention or indication of any pain, discomfort or weakness due to menarche in the novel. If there is anything that frustrates Lakshmi, it is the streak of confinements and restrictions that are suddenly imposed upon her during and after menarche.

\section{B. Child Marriage}

Child marriage is a traditional patriarchal practice which originates in menarche. The so called "leaky female body" with its ability to menstruate has been construed as "uncontrollable, excessive, expansive, disruptive, irrational and volatile" thus requiring constant control by men who are deemed "contained" and "rational" [6]. It is believed that a girl child is unable to exercise control over her emergent sexuality, necessitating constant surveillance by a man in the form of early marriage.

Hence, in order to safeguard Lakshmi's virtue and protect her from the dangers of illicit affairs and sexual transgressions that could tarnish the family honour, her mother decides to provide her with the care of a male guardian much before Lakshmi's so-called urges for copulation and propagation begin to show. As soon as Lakshmi reaches puberty, her mother starts looking for marriage proposals for her. Lakshmi is reduced to a mere aesthetic, sexual and reproductive body whose function is limited to becoming an ideal wife or mother. Her whole being is depicted to be codified in relation to men, never as an individual in her own right or in terms of her strengths, values and abilities as depicted in the excerpt below:

"My real potential, my mother decided, lay in my skin. Unlike her I was no Indian beauty but in a land of coffee-coloured people I was a cup of very milky tea. A prized, precious colour. A colour surely to be actively sought after in a wife, subtly encouraged in a daughter-in-law and lovingly cherished in one's grandchildren. Suddenly strange middle-aged ladies began to appear in our home. I was dressed to the nines and paraded in front of them. They all had the shrewd look of buyers in a diamond store. Their sharp beady eyes looked me over carefully for flaws, without the slightest trace of embarrassment" [16].

Child marriage has long-lasting and far-reaching consequences on a girl child's mind, body, and soul as she is yet to grasp the concepts of matrimony, womanhood, wifehood and motherhood. Take for instance the case of fourteen-year-old Lakshmi, who suffers from a great shock on 
her wedding night. Since she is given no prior knowledge of the sexual act, it comes to her as a disturbing, confusing and painful experience. Due to her own unpreparedness, lack of knowledge and her thirty-seven-year-old husband's rush for sex, she is left with permanent physical and psychological scars that makes it very difficult for her to visualise sex as anything more than an unavoidable duty. She never once looks upon intercourse as an enjoyable experience or as an emotional or affectional bonding between husband and wife. She is left so disgusted that she likens intercourse to the mating of dogs in the street. Everytime she has sex she feels disembodied. Her body is present but her mind is elsewhere. She is eager to escape the clutches of her husband and whatever it is he is doing to her. Marriage then turns out to be a troublesome social obligation for Lakshmi. The sacred facade of marriage lacks harmony and comes crumbling down due to emptiness: "From that moment on, love for me became the worm in the apple. Whenever my seeking mouth meets its soft body I destroy it and it in turn disgusts me" [16]. Such are the perils of child marriage. Child marriage has the ability to break and destroy a girl child. Lakshmi's conception of love is forever destroyed and this in turn destroys her at the end of the day - her inability to love fully and freely and display her emotions.

Child marriage also proves to be physically draining for Lakshmi. She is a victim of teenage pregnancy and multiple pregnancies. By the time she is nineteen-years-old, hardly more than a child herself, she is a mother of six children each born at intervals of one year.

Findings also reveal that early marriage curbs women's freedom and serves as a barrier for self-development. Because there was so much she could never have and so much she could never be, Lakshmi takes her self-sacrifices as a right to live through her children:

"She channeled all her furious energy into her children, pushing them towards unattainable limits: Being better, brighter and bolder was everything. Failure was a badly trained dog that lived in other people's houses. And when we did fail, which happened often, she took it as a personal affront...As the years went by she became an inconsolably unhappy woman and in turn she made us all unhappy" [16].

\section{Life as a Marketable Commodity}

The ancient Chinese traditional custom of mui tsai refers to "a patriarchal system of transferring unwanted girls, often as small children, from poor homes into rich families, who paid a nominal sum, sealing the bargain with a particular type of contract drawn up on red paper" [17]. These young girls are mostly sold for domestic servicing of men in return for basic necessities like food, water, clothes and shelter. They are not paid any wages.

In the novel, readers learn that after her thirteenth birthday, Mui Tsai's stepmother sells her to a broker in a tiny village in China who in turn sells her as a mui tsai to an old rich merchant in Malaya named Soong for a mere two hundred and fifty ringgit. Regarded as a mere burden, an extra mouth to feed and a huge liability to be shed, Mui Tsai's body is objectified and turned into a marketable commodity. She is reduced to a mere item of exchange in male transactions. Her status is no different from or no more than a piece of land, property or possession owned by a man. In other words, she is constructed as a thing - an object - rather than as an individual in her own right - a living, breathing, thinking, feeling subject.

Mui Tsai's owner, Old Soong, becomes the sole proprietor of her body and sexuality. As his commodity, it is entirely up to him to do with her as he pleases. Mui Tsai possesses little or no authority to make choices or decisions regarding her own life. Mui Tsai's body is enslaved and appropriated by patriarchy for a free supply of domestic labour. For the first two years, Mui Tsai does all the housework for her master. She performs the duties of a servant. She cooks, cleans, polishes, washes, serves and runs errands for Old Soong. In return, she is given a tiny room at the back of the mansion, a high thin-necked blouse and leftovers. She is ill-treated, beaten, slapped, pinched and abused.

Mui Tsai is also subject to repeated and escalating sexual harassment. Her body is reduced to the status of a sex object which is valued for nothing but the fleeting sexual gratification it can provide Old Soong. She is raped and taken as a concubine. In addition, she is forced into reproductive servitude. Old Soong takes the opportunity to produce heirs through Mui Tsai's youthful, healthy and fertile body since his three wives are barren. Mui Tsai's body then is reduced to a womb, a mere machine for reproductive purposes. She is regarded as nothing more than a medium, a vessel created by nature for the propagation of the all-important male line. All of Mui Tsai's five babies are taken away from her. Old Soong's actions leave deep physical, psychological and emotional scars on her body, mind and sense of self as depicted in the excerpt below:

"Her poor heart was broken and the bright light inside her skull had blown a fuse... After they stole Mui Tsai's fifth child, she shuffled around like a bitter ghost. Inside she was cut and bleeding...The giggling girl packed to bursting with mischievous intentions was gone, and in her place was a lost round face who would sniff audibly and wipe her face with the end of the sleeves. She was a small animal, her foot trapped in a mangle. Even in the shadows cast by my oil lamp I saw her silent, pitiful cries glittering in her eyes. They broke her like a toy, her mistresses and the master" [16].

Thus, it can be concluded that Mui Tsai's whole being is defined not in terms of some intrinsic value but in relation to men's needs. She is reduced to a material disembodied entity who exists only to provide services to men without a voice, self or identity of her own. Almost every existential condition of her body and mind is dexterously controlled by Old Soong and her effort at self-definition stifled.

\section{Sexual Violence within Marriage}

In the novel, the author shows readers that even when a woman has the right to choose her own life partner and marries out of love or mutual inclination, she is nevertheless vulnerable to a controlling relationship and different types of domestic violence. This can be attributed to marriage - an institution which embodies patriarchal power relations that result in male domination and female subordination. Duggan and Hunter [18] affirm that "marriage enforces and reinforces the linkage of gender with power by husband/wife categories that are synonymous with the social power imbalance between men and women". Hence, a contractual understanding of 
marriage presupposes the idea that a husband/man is to possess a wife/woman. This traditional view of marriage where a wife's body and sexuality is regarded as her husband's possession is evident in the relationship between Luke and Dimple.

Firstly, Dimple is a victim of sadomasochism. Sadomasochism denotes behaviours, fantasies and urges which trigger "acts (real, not stimulated) in which the individual derives sexual excitement and satisfaction from the psychological or physical suffering (including humiliation) of the victim" [19]. Among other things, sadomasochism involves restraint, blindfolding, spanking, whipping, rape and strangulation. The World Health Organisation (WHO) has classified sadomasochism as a severe form of mental health disorder. It is important to note that sadomasochistic acts can result in acute trauma, injury and death in victims.

Feminists lobby against sadomasochism as it is a practice which exploits women and the oppression of women for the purpose of men's sexual excitement and satisfaction. It eroticises, replicates, and reinforces power imbalances and the heterosexual patriarchal social pattern of male dominance and female submission which has long been considered as subjugating, oppressive and exploitative of women.

In the novel, readers learn that Luke pays a waiter five hundred ringgit to sleep with his wife of six years while he watched from afar. The thought of watching his wife having sex with another man aroused him. He told the waiter that his wife liked it rough. Clearly, he regarded his wife as nothing more than a sex object for his sensual gratification:

"His mind filled with a picture of the hussy, her legs, smooth and silky, wrapped around the waiter's naked torso. The liquid picture made him grasp for breath. Suddenly he wanted to know what reality looked like. Those small animal sounds she made in his bed, he wanted to watch from afar...The man felt the blood begin to pound in his head. It was not pain that he felt but a strange excitement..." [16].

Dimple is also a victim of marital rape. Marital rape refers to any unwanted sexual intercourse by a spouse committed without consent or obtained by threat and force. The topic of marital rape is a controversial one. In patriarchal societies, a wife's body is considered to be the husband's property. It is believed that marriage entitles a husband full access to his wife's sexuality and it is a wife's duty to fulfil her husband's sexual needs. As such, the question of marital rape does not arise for consent to marriage has been misinterpreted as consent to sexual intercourse.

However, through her fiction, Manicka voices her staunch opposition against marital rape by vividly describing it from a woman character's perspective. Readers learn firsthand of the fear, dread and pain associated with marital rape through Dimple's thought processes as she was being physically violated by her husband:

"He was waiting for me in my room. A gasp of shock swam out from somewhere deep inside me to see him lounging on my bed like a dark fate awaiting me on my clean white sheets. 'Come here,' he said in a voice like a whiplash. 'Dance for me, my darling.' 'I'm a bit tired tonight. I think I'll just shower and go straight to bed,' I said. I licked my dry lips and, panther quick, he had leaped off the bed, grabbed me by the arm and thrown me forcefully on the bed. For a few seconds I was too shocked to respond I simply stared up at him with huge frightened eyes. 'Too tired to dance? How about something a little different then, my fussy pussy,' he purred nastily... That night, there was pain like never before. When I opened my mouth to protest, to scream, he clamped his hand over it" [16].

Dimple was not only physically ravaged, but also psychologically affected by the incident. Her soul was injured and her personhood destroyed. She tried her best to separate her body from her mind and soul to escape the pain. At the end of the day, she turned to opium to block out the pain-filled reality and this killed her:

"It is true that your mind can float out and hover over you when it can no longer endure what is happening to your body. It floats above, looking down quite dispassionately, and thinks about mundane things like a drop of sweat gathering on your abuser's forehead, or if the rubbish bins have been put out for the refuse collectors. When he was finished Luke left me with an expression of disgust on his face..." [16].

In conclusion, it can be said that sexual violence within marriage is destructive to women. It results in long-lasting physical and psychological wounds. It betrays the very basis and essence of marriage as the bond of love and trust is violated. It also reduces women to mere sex objects. Marriage then becomes more of a sexual contract characterised by male domination and female subordination rather than a social contract meant for sealing the bond of love and strengthening the relationship between two individuals.

\section{E. Resistant Subjectivities}

What makes Manicka's novel a worthwhile literary endeavour is not the victim status of her women characters, but the ambivalence that results from the clash of voices in their subjectivities which eventually jolt them awake and urge them to resist patriarchy and hence disembodiment, allowing them to reclaim their body and sexuality.

A thorough analysis of the women characters' reveals the presence of tensions and instabilities in their subjectivities. Take for instance Lakshmi who is torn between her individual hopes, wishes and dreams on one hand, and patriarchal socio-cultural demands and expectations on her as a wife on the other. Lakshmi frankly admits that she does not want any of her children to take after their father: "She said his children from his first marriage were the sorriest creatures she ever saw" [16]. Unfortunately, much to Lakshmi's despise, "the Gods were getting careless with their gifts" [16]. Her fifth and sixth-born bear a strong resemblance to their father. Jeyan has "small dull eyes in a large square face and painfully thin limbs" while Lalita was "an extraordinarily ugly" "tiny mite" with the "colour and texture of bitter chocolate" [16]. Extremely unhappy with the situation at hand, Lakshmi takes active control over her own body and sexuality. She decides that she will not have any more children: "My brood, I decided, was complete. The pot was full. No more unguarded moments in the dark" [16].

Similarly, Mui Tsai eventually musters the courage to break free from domestic, sexual and reproductive servitude. She reflects upon her oppressive situation, reworks her subjectivity and brings about the change that she wishes for. It is implied in the novel that Mui Tsai escapes from Old Soong's mansion and sets out on her own as a prostitute: "And after that she was no longer sad...She went to a place where 
she had many babies and got to keep them all" [16]. Mui Tsai then finally recognises the power and value of her body. She manipulates her physique and appearance - her youthful body and pretty face — to bargain with patriarchy. Rather than allowing men free use of her body as she has always done, she makes them pay for her services. In addition to that, she uses men's weakness for sex to her advantage. She uses them to have babies and fulfil her long-thwarted dream to become a mother.

Katrak [9] points out that in certain situations like that of Mui Tsai's, prostitution can "constitute feminism in action". She argues that "women make strategic use of their bodies, often their only available avenue for resistance" [9]. This is exactly what Mui Tsai does. She uses the only power she has in a male society - her body — to bargain with patriarchy. Bakhtin [9] affirms that "such bodily expression is an important means of liberating human consciousness from a verbal, hierarchical perception of the work [to] opening up the possibility for a horizontal understanding of change.

The outside world may regard Mui Tsai as an insane woman, her decision to prostitute herself incomprehensible: "I think her mind snapped" [16]. However, Oppenheimer [20] argues that "what patriarchy defines as 'madness'.... is either the acting out of the devalued female role model or the total or partial rejection of one's sex role stereotype". True enough, Mui Tsai went against the traditional feminine role by prostituting herself. Oppenheimer [20] contends that women's descent into 'madness' can be seen as resistance to domination: "the reintegration into 'sanity' somehow feels like a loss - of potential, of possibility of self," whereas "the madness itself is a far from miserable state... a heady rush of delight, exultation, a pure sense of power in its sway". Thus, it can be said that Mui Tsai's 'madness' can be defined as a form of resistance to the erasure of her female self, body and sexuality in a phallic discourse.

Dimple too proves to be an active agent of resistance, seeking recognition as a subject in her own right by engaging in patriarchal bargains. For instance, when Dimple finds out that Luke has a mistress, "she becomes so cold and withdrawn...And with every year she freezes a little more" [16]. Dimple also develops a taste for giving her maternal family Luke's money: "Mother came to see me, wanting money... She needed five thousand. I gave her ten. I know Luke hates mother and he does sometimes questions big cash withdrawals but...Fuck him...I am developing a taste for giving Mother Luke's money" [16]. In addition, when she finds out that Luke pays a waiter five hundred ringgit to sleep with her to fulfil his sadomasochistic tendencies, she purposely engages in a one-night-stand with the waiter to show her protest. She stages the whole thing so that it looks like she is thoroughly enjoying the experience like she never did with her husband and hopes that Luke would divorce her in no time.

\section{CONCLUSION}

A thorough analysis of the women characters reveals that they suffer from a severe conflict between their sense of self and patriarchal impositions on their body and sexuality as manifested in the form of restrictions and confinements, rules of gender segregation, domestic servitude, sexual servitude, reproductive servitude and sexual violence. As a result, their subjectivity is repressed, resulting in disembodiment. However, this does not mean that these women characters are devoid of any participatory role in the construction of their selves. They are not reduced to docile bodies, with control totally residing in the powerful devices of surrounding discourses. They prove to be active agents of resistance, seeking recognition as subjects in their own right by engaging in patriarchal bargains through an awakened subjectivity. To conclude, it is my belief that the author incorporates both the women's sufferings and their attempt to break free from their oppression in an attempt to present a new, empowering image of women. By placing emphasis on the boundaries that women are not allowed to transgress and yet showing how those very boundaries get transgressed, the author produces a great if not an extraordinary story on female body politics.

\section{REFERENCES}

[1] C. $\mathrm{Ng}$ et al., Feminism and the Women's Movement in Malaysia: An Unsung (R)Evolution, OX: Routledge, 2010, ch. 7, pp. 133-134.

[2] C. Jerome. Sexual identities of the Malay male in Karim Raslan's Go East and Neighbours. Online Journal of Language Studies. [Online] 8(1). pp. 34-46. Available: http://www.ukm.my/ppbl/GEMA\%20vo $1 \% 208 \% 20 \% 281 \% 29 \% 202008 /$ abs\%20p_35_46_v_8\%281\%29.pdf

[3] J. Kristeva, "Talking about polylogue," Feminsit Literary Theory: A Reader, 3rd ed. Oxford: Wiley-Blackwell, 2010, pp. 284-286.

[4] H. Cixous, "The laugh of the medusa," An Anthology of Literary Theory and Criticism, NJ: Rutgers University Press, pp. 347-362.

[5] E. Grosz, "Notes towards a corporeal feminism," Australian Feminist Studies, vol. 2, no. 5, pp. 1-15, 1987.

[6] E. Grosz, Volatile Bodies: Towards a Corporeal Feminism, London, UK: Routledge, 1994.

[7] E. Grosz, Space, Time and Perversion, NY: Routledge, 1995, pp. 32-33.

[8] D. Kandiyoti, "Bargaining with patriarchy," Gender and Society, vol. 2, no. 3, pp. 274-290, 1988.

[9] K. Katrak, The Politics of the Female Body: Postcolonial Women Writers, Piscataway, NJ: Rutgers University Press, 2006, pp. 3-32.

[10] B. Davies, Poststructuralist Theory and Classroom Practice, Geelong, Victoria: Deakin University Press, 1994, p. 3

[11] C. Weedon, Feminist Practice and Poststructuralist Theory, Oxford, OX: Blackwell, 1987, p. 32.

[12] L. Summers, Bound to Please: A History of the Victorian Corset, Oxford, OX: Berg, 2003, p. 129.

[13] L. Alcoff, "Cultural feminism versus post-structuralism: The identity crisis in feminist theory," Signs, vol. 13, no. 3, 1988, p. 425.

[14] D. Hall, Subjectivity, New York, NY: Routledge, 2004, p. 127.

[15] R. Bernard, The Physiological Enigma of Woman: The Mystery of Menstruation, New York, NY: Kessinger Publishing, 2010, p. 55

[16] R. Manicka, The Rice Mother, London: Hodder \& Stoughton, 2002.

[17] S. Miers and M. Jaschok, Women and Chinese Patriarchy: Submission, Servitude and Escape, HK: Hong Kong University Press, 1994, p. 180.

[18] L. Duggan and N. Hunter, Sex Wars: Sexual Dissent and Political Culture, New York, NY: Routledge, 2006, p. 110.

[19] D. Rowland and L. Incrocci, Handbook of Sexual and Gender Identity Disorders, Hoboken, NJ: Wiley, 2008, p. 496.

[20] J. Oppenheimer, Private Demons, NY: Putnam's Sons, 1988, p. 164.

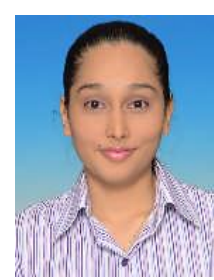

Manmeet Kaur Senthok Singh was born in Kuala Lumpur, Malaysia. She is currently residing in Ipoh, Perak. She has an MA degree in linguistics and English language studies from the University of Science Malaysia and a BA (Hons) degree in English language from Universiti Tunku Abdul Rahman. She is currently with the Department of Languages and Linguistics, Faculty of Arts and Social Science, Universiti Tunku Abdul Rahman (Perak Campus). She teaches linguistics, sociolinguistics, English morphology and syntax and a variety of ESP papers. Her research interests include new literatures in English (critical theory), emerging varieties of English, gender and sexuality studies and feminist stylistics. 